\title{
Home Garden; an Approach for Household Food Security and Uplifting the Status of Rural Women: A Case Study of Saptari, Nepal
}

\author{
Sagar Bhandari ${ }^{1, a, *}$, Pankaj Kumar Yadav ${ }^{1, b}$ and Sramika Rijal ${ }^{2, c}$ \\ ${ }^{I}$ Agriculture and Forestry University, Rampur, Chitwan, Nepal \\ ${ }^{2}$ Department of Agri Botany and conservation Ecology, Agriculture and Forestry University, Nepal
}

*Corresponding author

\section{A R T I C L E I N F O A B S T R A C T}

Research Article

Food security is one of the major global challenges of the twenty-first century. World population is expected to increase by one-third, between 2009 and 2050, and in Asia, crop yield is estimated to decline by 5 to $30 \%$ from 2050 onwards compared to 1990 . It is high time to seek alternatives that can increase production utilizing existing resources ensuring food security. A home garden can be

Received : 01/03/2021

Accepted : 07/09/2021 a viable and sustainable alternative in this regard; nevertheless, it is often neglected. Thus, this study aims to understand the role of the home garden in maintaining household food security and enhancing rural women's status in Nepal. Two villages of Bishnupur rural municipality, namely, Bajitpur and Musharniya were selected as study sites. $78.6 \%$ of households in Bajitpur and $68.4 \%$ households in Musharniya were found to have a home garden where crops and livestock were

Keywords:

Balanced diet

Nutrition security

Organic

Sustainability

Women status organized in an integrated way. The home garden was found to maintain household food security, ensure food availability for most of the seasons, access of household members to food, its utilization, and stability in production. Furthermore, $66.67 \%$ and $58.33 \%$ of women sold surplus home garden products in Bajitpur and Musharniya respectively. This signifies the role of home gardening activities in uplifting the social and economic status and, farming knowledge of rural women in both villages. However, there is a lack of extension facilities and subsidies for the home garden to encourage farmers. Therefore, different models of home gardens should be developed and disseminated, prioritizing the integration of the scientific farming system with traditional knowledge for sustainable adoption of the home garden in Nepal.

sagarbhandari88484@gmail.com srijal@afu.edu.np
(iD)https://orcid.org/0000-0002-4745-3184| b@premsaimon2@gmail.com (iD) https://orcid.org/0000-0002-7893-5063 https://orcid.org/0000-0002-4725-5153

\section{Introduction}

Home garden, the oldest agroecosystem (Nair, 2001), is an area around a homestead where different vegetables, fruits, herbs, etc are grown throughout the year for their consumption, potentially integrated with animal production (Keatinge et al., 2012). In Nepal, the home garden is locally called 'bari' in terai and 'vegetable bari' in the hills area (Shrestha et al., 2001). Christian et al. (2004) reported that the purpose of the home garden varies from subsistence agriculture to commercial production. In developing countries like Nepal, the reasons for having a home garden are mainly to maintain household food and nutrition security (Musotsi et al., 2008; Galhena et al., 2013) and to save food expenditure (Martin et al., 2000). In addition, Kumar \& Nair (2004) reported that they could be a source of income to fulfil other basic needs. The combination of the components of a home garden is determined by the needs and preferences of the household members (Vogl et al., 2002). However, its structure is also determined by the socio-cultural characteristics of the locals (Kumar \& Nair, 2004). It provides required nutrition and a balanced diet to the family members; it is often termed a Primary Health Centre (Thapa, 2004). Home gardens are often used as a site of experimentation, introduction, and domestication of the plants (Shrestha et al., 2001; Engels, 2002; Gautam et al., 2004)

In Asia, crop yields are estimated to decline by 2.5 to $10 \%$ from 2020 onwards and by 5 to $30 \%$ from 2050 onward compared with 1990 levels with South and Central Asia hit hardest (Cruz et al., 2007). FAO (2009) estimated that the world population would be increased by one-third by 2050 . Food security is one of the most significant challenges of today's world. Keeping this in mind, we have to seek many more alternatives to maintain sustainable food security. Pinstrup-Andersen (2009) interprets food security as the availability of enough food, whether at the global, national, community, or household level. Food security is said to be achieved if there is food availability, access to food, 
utilization, and stability in its production. In this regard, the home garden plays a crucial role in maintaining household food security and decreasing vulnerability amongst households (Buchmann, 2009). Kennedy et al. (2003) revealed that the micronutrients deficiency is due to a lack of diversity in diet. Most of the population of rural areas is poor in Nepal. They neither afford vegetables and fruits from the market nor have access to the market; they hardly purchase vegetables for one to two months in a year (Gautam et al., 2006). For such people, a home garden is the only source of fruits and vegetables. Though home garden has a vital role in maintaining household food security, biodiversity conservation, and income generation, this sector is still neglected. This negligence is because home gardening is predominantly seen as a women's issue (Meinzen-Dick et al., 2012; Adekunle, 2013) as well as due to their small size (Sthapit et al., 2004).

As the role of the home garden in household food security is neglected, in the same way, the role of women in household activities is overlooked in typical Nepalese rural society. In Nepal, women's role is limited in household activities, bearing, and rearing children. Globally, about $43 \%$ of workers engaged in agricultural activities are women (Akter et al., 2017). Meinzen-Dick et al. (2012) revealed that strengthening the position of women leaves a positive impact on the health and nutritional status of the household. Home gardens, directly or indirectly, uplift the status of rural women by improving their knowledge about farm management, and economic and social status. In this context, microscopic researches are conducted in Nepal. So, this research aims to understand how the role of the home garden is significant in maintaining household food security and enhancing rural women's status.

\section{Study Area}

The study was conducted in the Bishnupur rural municipality of Saptari district of province 2 to discover the status of the home garden and its role in maintaining household food security and uplifting the status of rural women. Two villages of Bishnupur rural municipality, namely, Bajitpur (ward 01) and Musharniya (ward 03), were selected as survey sites.

\section{Sampling Design}

The study was confined to households with more than 0.2 hectare of land and who are actively engaged in agricultural activities. There were altogether 97 such households in both wards. The sample size was determined with a $95 \%$ level of confidence. Forty-two households in Bajitpur village and thirty-six households in Musharniya village were randomly selected using simple random sampling techniques. The study was conducted from September to October 2020 by using pre-tested questionnaires.

\section{Data Analysis}

Data were analysed in Microsoft Excel software. Z- test was computed to know whether the mean of different socioeconomic characteristics of household head and, structure and components of the home garden of Bajitpur and Musharniya were significantly different. A Chi-square test was done to determine the relationship between the adoption status of home garden and socio-economic characteristics.

\section{Results}

\section{Demographic Profile of the Respondent}

The demographic and socio-economic characteristics of household heads are presented in Table 1. The average age of Bajitpur is significantly different from that of Musharniya at 5\% significance level. Joint family is common in both villages with an average family size of 7.35 and 7.19 in Bajitpur and Musharniya respectively. Male-dominated households were prevalent in both villages. The predominant ethnicity is Dalits in Bajitpur whereas Madhesi in Musharniya. The average of Madhesi and Dalits households is significantly different between the two villages at a 5\% significance level. The average household head receiving at least a secondary level of education is 0.309 in Bajitpur and 0.278 in Musharniya which is significantly different at $1 \%$ significance level.

As agriculture is the predominant primary occupation of both villages, only a few of them have practised off-farm activities. Only a few household heads have access to credit and this result is significantly different between the two villages at a 5\% level of significance. Household head receiving extension services is significantly greater in Bajitpur than that of Musharniya at a 1\% significance level. Both villages have an average total land size of less than a hectare. The majority of the house has a home garden with an average size of 0.069 ha in Bajitpur and 0.066 in Musharniya. The reasons for practicing home gardens are illustrated in figure 2. The main reason behind practicing home gardens in Bajitpur is to maintain household food security while that in Musharniya is to generate income to fulfil other basic needs. Socioe-conomic characteristics of household head in the study area is presented in Table 1.

\section{The Status of Home Garden in the Study Area}

Various variables characterizing the structure and components of the home garden are presented in Table 2. Three types of home gardens, namely bari, tarkari bari and phulbari were found in both villages. The most prevalent type of home garden in Bajitpur was tarkari bari whereas that in Musharniya was bari. Average households having bari is significantly greater in Musharniya than that in Bajitpur at a $10 \%$ significance level. Similarly, the average household having tarkari bari is significantly greater in Bajitpur than that of Musharniya at a $1 \%$ level of significance. In both villages, home gardens with wooden/bamboo fencing were dominant followed by live fencing. The average household which did not adopt any fencing method for a home garden was 0.333 in Bajitpur and 0.111 in Musharniya which are significantly different at a $5 \%$ significance level.

The majority of the households were found to rear ruminant animals. Households rearing small ruminants are significantly greater in Bajitpur at a 5\% significance level. Home garden having large ruminants is 0.857 in Bajitpur and 0.527 in Musharniya which is significantly different at $1 \%$ level of significance. The dominant cultivated species are vegetables in both villages. The average household practicing off-season farming in Bajitpur was 0.524 and that in Musharniya was 0.361 . The main source of fertilizer in both villages was organic. Very few households were found to use chemical pesticides with an average of 0.21 and 0.22 in Bajitpur and Musharniya respectively. 
Table 1. Demographic and socio-economic characteristics of the household head of Bajitpur and Musharniya villages

\begin{tabular}{|c|c|c|c|c|c|c|}
\hline \multirow{2}{*}{ S.N. } & \multirow{2}{*}{ Variable } & \multicolumn{2}{|c|}{ Bajitpur $01(n=42)$} & \multicolumn{2}{|c|}{ Musharniya $(n=36)$} & \multirow{2}{*}{$\mathrm{Z}$ value } \\
\hline & & Mean & S.D. & Mean & S.D. & \\
\hline 1 & Age (years) & 44.880 & 9.010 & 48.500 & 6.520 & $2.051 * *$ \\
\hline 2 & Family size & 7.350 & 2.058 & 7.190 & 2.026 & 0.345 \\
\hline 3 & Gender male $(1 / 0)$ & 0.857 & 0.354 & 0.860 & 0.350 & 0.134 \\
\hline \multirow[t]{3}{*}{4} & Ethnicity & & & & & \\
\hline & Madhesi (1/0) & 0.357 & 0.485 & 0.638 & 0.487 & $2.552 * *$ \\
\hline & Dalits $(1 / 0)$ & 0.642 & 0.485 & 0.361 & 0.487 & $2.544 * *$ \\
\hline 5 & At least secondary education of household head (1/0) & 0.309 & 0.468 & 0.278 & 0.446 & $2.990 * * *$ \\
\hline 6 & Primary occupation as an Agriculture (1/0) & 0.786 & 0.415 & 0.806 & 0.401 & 0.216 \\
\hline 7 & Off farm activity (1/0) & 0.262 & 0.445 & 0.142 & 0.355 & 1.323 \\
\hline 8 & Credit access $(1 / 0)$ & 0.547 & 0.504 & 0.300 & 0.467 & $2.240 * *$ \\
\hline 9 & Has got extension activities (1/0) & 0.547 & 0.504 & 0.194 & 0.401 & $3.440 * * *$ \\
\hline 10 & Total land size (ha) & 0.868 & 0.634 & 0.779 & 0.502 & 0.690 \\
\hline 11 & Having home garden $(1 / 0)$ & 0.786 & 0.415 & 0.694 & 0.468 & 0.910 \\
\hline 12 & Home garden area (ha) & 0.069 & 0.061 & 0.066 & 0.079 & 0.185 \\
\hline
\end{tabular}

Table 2. Assessment of the structure and components of home garden

\begin{tabular}{|c|c|c|c|c|c|}
\hline \multirow{2}{*}{ Variable } & \multicolumn{2}{|c|}{ Bajitpur $01(n=42)$} & \multicolumn{2}{|c|}{ Musharniya $03(n=36)$} & \multirow{2}{*}{$\mathrm{Z}$ value } \\
\hline & Mean & S.D. & Mean & S.D. & \\
\hline \multicolumn{6}{|l|}{ Types of home garden } \\
\hline a. Bari (close to home, vegetable dominant) $(1 / 0)$ & 0.381 & 0.492 & 0.583 & 0.500 & $1.790 *$ \\
\hline b. Tarkari bari (away from home, vegetable dominant) (1/0) & 0.452 & 0.504 & 0.139 & 0.351 & $3.210 * * *$ \\
\hline c. Phulbari (mostly fruit of single species is cultivated) $(1 / 0)$ & 0.357 & 0.485 & 0.278 & 0.454 & 0.740 \\
\hline \multicolumn{6}{|l|}{ Fencing status of home garden } \\
\hline a. No fencing $(1 / 0)$ & 0.333 & 0.477 & 0.111 & 0.311 & $2.460 * *$ \\
\hline b. Live fencing $(1 / 0)$ & 0.073 & 0.261 & 0.111 & 0.318 & 0.570 \\
\hline c. Wooden / bamboo stake fencing (1/0) & 0.428 & 0.501 & 0.472 & 0.506 & 0.380 \\
\hline \multicolumn{6}{|l|}{ Livestock in home garden } \\
\hline a. Small ruminants $(1 / 0)$ & 0.857 & 0.354 & 0.611 & 0.494 & $2.490 * *$ \\
\hline b. Large ruminants $(1 / 0)$ & 0.857 & 0.354 & 0.527 & 0.506 & $3.280 * * *$ \\
\hline c. Poultry $(1 / 0)$ & 0.18 & 0.397 & 0.222 & 0.421 & 0.450 \\
\hline \multicolumn{6}{|l|}{ Cultivated species in home garden } \\
\hline a. Vegetables $(1 / 0)$ & 0.714 & 0.457 & 0.639 & 0.487 & 0.700 \\
\hline b. Fruits $(1 / 0)$ & 0.429 & 0.503 & 0.361 & 0.487 & 0.601 \\
\hline c. Spices crops $(1 / 0)$ & 0.64 & 0.485 & 0.527 & 0.506 & 1.002 \\
\hline d. Ornamental $(1 / 0)$ & 0.143 & 0.354 & 0.086 & 0.28 & 0.793 \\
\hline e. Fodder $(1 / 0)$ & 0.524 & 0.505 & 0.361 & 0.487 & 1.440 \\
\hline Off season cultivation $(1 / 0)$ & 0.524 & 0.505 & 0.361 & 0.487 & 1.440 \\
\hline Organic sources of fertilizer $(1 / 0)$ & 0.64 & 0.485 & 0.583 & 0.500 & 0.500 \\
\hline Pesticide use $(1 / 0)$ & 0.21 & 0.415 & 0.222 & 0.422 & 0.126 \\
\hline
\end{tabular}

Note: $*, * *$ and $* * *$ indicate $10 \%, 5 \%$ and $1 \%$ level of significance respectively.

The Role of Home Garden in Maintaining Household Food Security in the Study Area

The contribution of the home garden to maintain household food security is presented in Table 3. As the majority of the households have a home garden, it is the main source of vegetables in both villages followed by the local market and neighbour. The year-round availability of vegetables from home garden was $28.57 \%$ in Bajitpur and $30.56 \%$ in Musharniya. Average vegetable consumption per person above 300 grams in each household is $66.67 \%$ in Bajitpur and $63.89 \%$ in Musharniya. It was computed from the average of the last five days. $78.57 \%$ of households were found to sell surplus produce of home garden in Bajitpur while that in Musharniya is $69.44 \%$. Most of them took to the local market also called 'haat bazaar' in the local language. The majority of the households were found to earn below 1 lakh annually by selling home garden products in both villages. As vegetable is the dominant crop in a home garden, most of the households were found to sell vegetables with the percentage of 76.19 in Bajitpur and 61.11 in Musharniya. Mostly sold livestock products were found to be milk followed by meat and eggs. The edible species reported in most of the home gardens were mango and leafy vegetables (73.81\%) in Bajitpur whereas chilli (72.22) in Musharniya. The top eleven edible species reported in the home garden in the study area are illustrated in figure 3 .

\section{The Role of Home Garden in Uplifting the Status of}

\section{Rural Women in the Study Area}

Table 4 reveals the factors responsible for uplifting women's status. The majority of the women were decisionmakers in both villages with an average percentage of 61.90 in Bajitpur and 44.44 in Musharniya. $66.67 \%$ of women are involved in selling surplus home garden products in Bajitpur whereas 58.33\% in Musharniya. Most of the women were found to keep money earned after selling home garden products in both villages. 
Table 3. Home garden for household food security

\begin{tabular}{|c|c|c|}
\hline Variables & Bajitpur 01(n=42) & Musharniya $03(n=36)$ \\
\hline \multicolumn{3}{|l|}{ Sources of vegetables } \\
\hline Home garden & $28(66.67)$ & $16(44.44)$ \\
\hline Local market & $22(52.38)$ & $15(41.67)$ \\
\hline Neighbour & $20(47.61)$ & $14(38.89)$ \\
\hline \multicolumn{3}{|l|}{ Availability of vegetables from home garden } \\
\hline Less than 100 days & $5(11.90)$ & $3(8.33)$ \\
\hline 100 to 200 days & $6(14.28)$ & $5(13.80)$ \\
\hline 200 to 300 days & $10(23.81)$ & $6(16.67)$ \\
\hline Year round available & $12(28.57)$ & $11(30.56)$ \\
\hline \multicolumn{3}{|l|}{ Annual income earned by selling home garden products } \\
\hline Below 1 lakh & $10(23.81)$ & $8(22.22)$ \\
\hline 1 to 2 lakhs & $7(16.67)$ & $5(13.80)$ \\
\hline 2 to 3 lakhs & $10(23.81)$ & $6(16.67)$ \\
\hline Above 3 lakhs & $6(14.29)$ & $6(16.67)$ \\
\hline Sell surplus produce & $33(78.57)$ & $25(69.44)$ \\
\hline \multicolumn{3}{|l|}{ Crop species which they sell } \\
\hline Vegetables & $32(76.19)$ & $22(61.11)$ \\
\hline Fruits & $13(30.95)$ & $7(19.44)$ \\
\hline Spices & $20(71.42)$ & $5(61.11)$ \\
\hline \multicolumn{3}{|l|}{ Livestock products which they sell } \\
\hline Meat & $28(66.67)$ & $18(50)$ \\
\hline Milk & $33(78.57)$ & $18(50)$ \\
\hline Eggs & $6(14.29)$ & $6(13.88)$ \\
\hline \multicolumn{3}{|l|}{ Methods of selling home garden products } \\
\hline Sell at the site of production & $12(28.57)$ & $7(19.44)$ \\
\hline Taken to the local market/ haat-bazar & $15(35.71)$ & $12(33.33)$ \\
\hline Home delivery & $6(14.29)$ & $6(13.88)$ \\
\hline
\end{tabular}

Note: Figure in the parenthesis () indicates the percentage.

Table 4. Assessment of social and economic upliftment of women through home garden activities

\begin{tabular}{l|cc}
\hline \multicolumn{1}{c|}{ Variables } & Bajitpur 01(n=42) & Musharniya 03 $(\mathrm{n}=36)$ \\
\hline Women as a decision-maker & $26(61.90)$ & $16(44.44)$ \\
Women involved in selling home garden products & $28(66.67)$ & $21(58.33)$ \\
Women who kept money by selling home garden products & $29(69.05)$ & $21(58.33)$ \\
Women involved in home garden activities as well as in social organizations & $27(64.28)$ & $20(55.56)$ \\
Women took part in extension activities & $6(14.28)$ & $3(8.33)$ \\
\hline
\end{tabular}

Note: Figure in the parenthesis indicates the percentage.

Table 5. Assessment of the relation between Socio-economic characteristics and adoption status of home garden

\begin{tabular}{|c|c|c|c|c|c|c|c|}
\hline \multicolumn{2}{|c|}{ Socio-economic variables } & \multicolumn{3}{|c|}{ Bajitpur $01(n=42)$} & \multicolumn{3}{|c|}{ Musharniya $03(n=36)$} \\
\hline Variables & Categories & Adopters & Non-adopters & $\chi^{2}$ & Adopters & Non-adopters & $x^{2}$ \\
\hline \multirow{2}{*}{ Gender } & Male & 30 & 3 & \multirow{2}{*}{$13.07 * * *$} & 22 & 9 & \multirow{2}{*}{0.37} \\
\hline & Female & 3 & 6 & & 3 & 2 & \\
\hline \multirow{4}{*}{ Education } & Illiterate & 5 & 0 & \multirow{4}{*}{$19.36 * * *$} & 2 & 5 & \multirow{4}{*}{$8.76 * *$} \\
\hline & Primary & 15 & 6 & & 15 & 4 & \\
\hline & Secondary & 11 & 2 & & 7 & 2 & \\
\hline & Post-secondary & 2 & 1 & & 1 & 0 & \\
\hline \multirow{3}{*}{ Age (years) } & Below 30 & 0 & 1 & \multirow{3}{*}{$4.606^{*}$} & 0 & 0 & \multirow{3}{*}{2.21} \\
\hline & $30-60$ & 31 & 8 & & 24 & 11 & \\
\hline & 60 above & 2 & 0 & & 1 & 0 & \\
\hline \multirow{2}{*}{ Ethnicity } & Madhesi & 14 & 1 & \multirow{2}{*}{$3.40 *$} & 20 & 7 & \multirow{2}{*}{1.09} \\
\hline & Dalit & 19 & 8 & & 5 & 4 & \\
\hline \multirow{3}{*}{ Landholders } & $<0.1$ ha & 1 & 0 & \multirow{3}{*}{$5.56^{*}$} & $\mathrm{O}$ & 5 & \multirow{3}{*}{$13.35 * * *$} \\
\hline & $0.1-1$ ha & 21 & 3 & & 21 & 4 & \\
\hline & $>1$ ha & 11 & 6 & & 4 & 2 & \\
\hline \multirow{2}{*}{ Primary Occupation } & Agricultural & 30 & 5 & \multirow{2}{*}{$5.648 * *$} & 22 & 7 & \multirow{2}{*}{$2.74 *$} \\
\hline & Non -Agricultural & 3 & 4 & & 3 & 4 & \\
\hline
\end{tabular}

Note: *,** and $* * *$ indicate $10 \%, 5 \%$ and $1 \%$ level of significance respectively. 


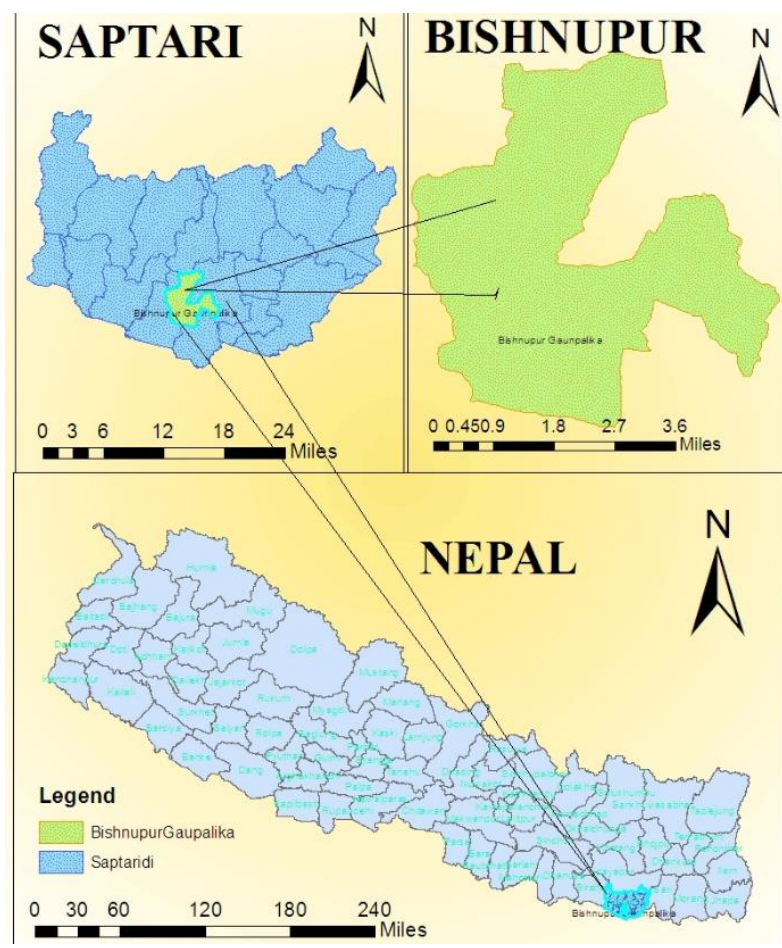

Figure 1. Map of Nepal showing the study area

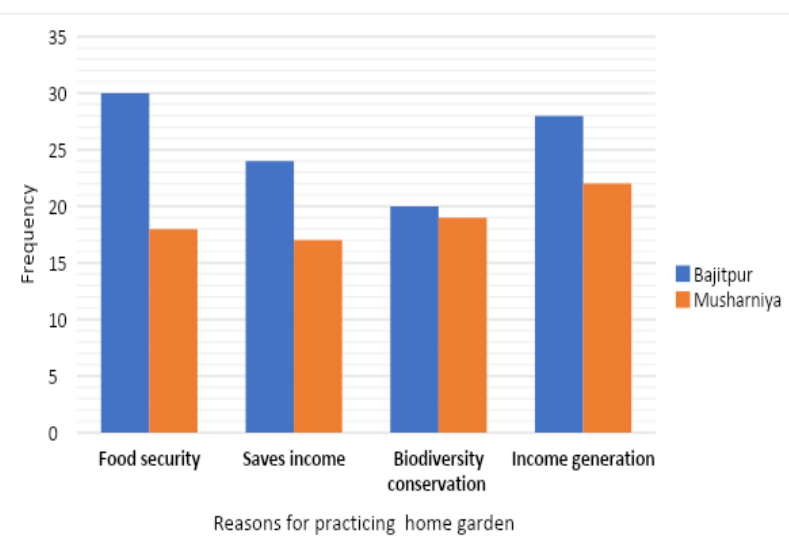

Figure 2. Reasons for the adoption home garden in Bajitpur and Musharniya

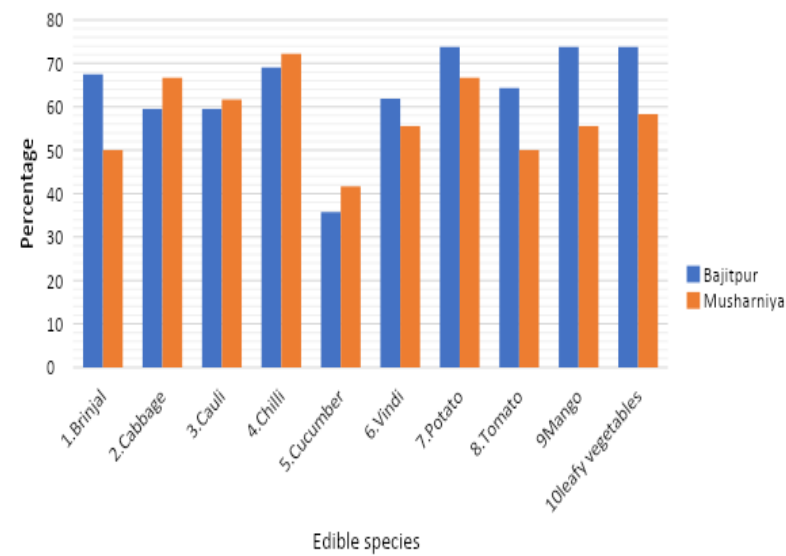

Figure 3. Top 11 edible species reported in home garden in Bajitpur and Musharniya.
The majority of the women who were actively engaged in home garden activities were also found to involve in social organization. But very few women got the chance to receive extension services with the percentage of 14.28 in Bajitpur and 8.33 in Musharniya.

\section{The Relationship Between Socio-economic} Characteristics of Household Heads and the Adoption Status of Home Garden

Table 5 shows the relationship between the socioeconomic characteristics of the household head and the adoption status of the home garden.Adoption status is significantly related to gender in Bajitpur at a $1 \%$ significance level. The education level of the household head is significantly related to adoption status at $1 \%$ and $5 \%$ significance level in Bajitpur and Musharniya respectively. Similarly, significant relationships were found between the age group and adoption status and also between ethnicity and adoption status at a $10 \%$ significance level in Bajitpur. The relationship between land size and adoption status is significant at a $10 \%$ significance level in Bajitpur and at a $1 \%$ significance level in Musharniya. The primary occupation of the household head is significantly related to adoption status at a 5\% significance level in Bajitpur and a 10\% significance level in Musharniya.

\section{Discussion}

There was the domination of patriarchal and joint families in both Bajitpur and Musharniya villages. Most of the households surveyed were of Madhesi and Dalits with poor educational status. Due to a lack of education, most of them were engaged in subsistence farming. Very few households which have got extension facilities and credits were found practicing commercial farming. The majority of the households have a home garden but with a small area. About $72 \%$ of households have home gardens of an area of 2 to $11 \%$ of the total land holding in Nepal (Gautam et al., 2006). However, our findings were slightly greater as our study was concentrated in remote areas and obviously, the remote area has a greater percentage of the home garden than that of the urban area. Most of them were reported practicing home gardens mainly for food security and income generation. Apart from providing food and nutrition security and economic benefits, it also plays a vital role in the in-situ conservation of biodiversity and genetic materials (Trinh et al., 2003).

A greater number of home gardens were of vegetables dominant in both villages. In a study carried out by Gautam et al. (2006) shows that home garden supplies $60 \%$ of the household's total fruits and vegetable consumption. Almost the entire home garden had cultivated crops and livestock in an integrated way reflecting rural subsistence farming. They had reared small ruminants such as goat for meat, and income source and, large ruminants such as cow, buffalo, and bull for milk, meat and draft purposes. Offseason cultivation was practised by some of the households that have received agriculture-related training and subsidies. The major source of fertilizer was organic, mainly Farm Yard Manure (FYM) and vermicompost. As the majority of the home gardens were restricted from chemical pesticides, their products are healthy for human consumption. The home garden plays a vital role in 
maintaining household food security by ensuring availability, accessibility, stability in production, and utilization of crops and livestock products in a better way. The majority of the households having home gardens were found to meet U.S. dietary guidelines of vegetable consumption that is more than $300 \mathrm{~g}$ per day per person. Diverse products of the home garden such as different species of fruits and vegetables, spices, milk, meat, eggs help to maintain household nutrition security. Shrestha et al. (2001) also revealed that the home garden plays a vital role in supplying household members with a diversity of different food crops. Furthermore, they are the sources of income for rural farmers by selling surplus produce. Households that were involved in off-season farming were found to sell surplus produce mainly of fruits and vegetables. And those who were involved in subsistence farming were found to sell mainly livestock products such as milk and eggs. The demand for home garden products in the market is relatively higher as they are organic and cheaper.

The home garden has a significant role in the upliftment of rural women status. Women were involved in greater proportion as compared to men in the cultivation of vegetables in the home garden which aids to increase their knowledge about farming practices. They decide with men for the selection of crops, livestock, and other farming practices related to the home garden. The majority of the women have to interact and deal with their customers while selling home garden products which helps to raise their social status. The majority of the women who were engaged in home garden activities, were also found to engage in social organizations such as Sita Laghu Uddham Samuha, Bishnupur Mahila Samuha, and Mahila Udham Sahakari. The status of rural women can be increased efficiently through their active participation in home garden-related projects. Research done in Bangladesh shows that women's participation in the NGO Gardening and Nutrition Education Surveillance Project, a homestead gardening project, empowers women by enhancing new skills on improved gardening practices, as well as strengthening information sharing and dissemination (Bushamuka et al., 2005). In our study, women were found handling financial matters; deposit income and take loans for off-season farming and use the money for other household activities, ultimately raising their economic status. Thus, all these activities related to home gardens help to raise the social and economic status and also to increase knowledge about farming practices of the rural women of Bajitpur and Musharniya.

\section{Recommendations}

Based on the findings of our study, the following recommendations were made:

- Traditional knowledge of farmers should be integrated with scientific knowledge for rapid adoption of scientific production technologies and sustainability of the home garden.

- The fresh and organic products of the home garden should have market security with the optimum price to encourage farmers in home garden activities.
- $\quad$ Provisions of subsidies and training should be made by the government to facilitate off-season production in the home garden.

- Home garden-related extension facilities should be mainly targeted towards women as it has dual advantages; increase production and also helps to raise women's social and economic status.

\section{Conclusion}

This study shows that home gardens are the source of diverse fresh vegetables and livestock products that ensure nutrition security to the household members. At the same time, it also ensures household food security as vegetables are available for most of the seasons from the home garden. As home garden products are fresh and free from chemical pesticides, they maintain the health of consumers. Furthermore, they are the source of income that can be used to fulfil other basic needs. Besides maintaining food and nutrition security and generating income, they also possess a vital role in enhancing the status of rural women. Women decide on the home gardening activities with men and also actively engage in selling surplus produce which aid in their socio-economic upliftment. They get a chance to increase farming knowledge by engaging in home garden activities. As mentioned above, a home garden has the potential to maintain household food security and to uplift rural women's status, nevertheless, its importance has been overlooked may be due to its small size. It should be noted that to maintain food security in the country, there should be food and nutrition security in each household at first. For this home garden is indispensable. Future research work is suggested in the following areas:

- Development of different suitable models of home garden considering geography, climate, and household needs.

- Post-harvest management of home garden products in a convenient way, so that they can be used during the lean period.

- Assessment of the efficiency of different homestead gardening projects in increasing the status of rural women through home gardening activities.

- Biodiversity conservation in a home garden.

\section{References}

Adekunle OO. 2013. The role of home gardens in household food security in Eastern Cape: A case study of three villages in Nkonkobe Municipality. Journal of Agricultural Science, 5(10): 67-76. doi:10.5539/jas.v5n10p67

Akter S, Rutsaert P, Luis J, Htwe NM, San SS, Raharjo B, Pustika A. 2017. Women's empowerment and gender equity in agriculture: A different perspective from Southeast Asia. Food Policy Elsevier, 69: 270-279. doi: https://doi.org/ 10.1016/j.foodpol.2017.05.003

Buchmann C. 2009. Cuban home gardens and their role in socialecological resilience. Human Ecology, 37(6): 705-721. doi: 10.1007/s10745-009-9283-9

Bushamuka VN, de Pee S, Talukder A. 2005. Impact of a homestead gardening program on household food security and empowerment of women in Bangladesh. Food and Nutrition Bulletin, 26(1): 17-25. doi: https://doi.org/ $10.1177 / 156482650502600102$ 
Christian R, Vogl-Lukasser B, Puri RK. 2004. Tools and methods for data collection in ethnobotanical studies of home gardens. Field Methods, 16(3): 285-306.

Cruz RV, Harasawa H, Lal M, Wu S, Anokhin Y, Punsalmaa B, Honda Y, Jafari M, Li C, Ninh NH. 2007. Asia. Climate Change 2007: Impacts, Adaptation and Vulnerability. Contribution of Working Group II to the Fourth Assessment Report of the Intergovernmental Panel on Climate Change. Cambridge University Press, Cambridge, UK. 469-506

Engels J. 2002. Home gardens-a genetic resources perspective. Home Gardens and in Situ Conservation of Plant Genetic Resources in Farming Systems, 3.

FAO, 2009. Climate changes and bioenergy challenges for food and agriculture. Issues brief. High-level expert forum. Rome, 12-13 Oct 2009. Available from http://www.fao.org/wsfs/ forum2050/wsfs-background-documents/hlef-issuesbriefs/en/. (Accessed 10 Mar 2020).

Galhena DH, Freed R, Maredia KM. 2013. Home gardens: a promising approach to enhance household food security and wellbeing. Agriculture and Food Security 2(1): 1-13.

Gautam R, Suwal R, Shrestha P. 2006. Status of home gardens of Nepal: Findings of baseline survey conducted in four sites of home garden project. Home Gardens in Nepal: Proceeding of a Workshop on" Enhancing the Contribution of Home Garden to on-Farm Management of Plant Genetic Resources and to Improve the Livelihoods of Nepalese Farmers: Lessons Learned and Policy Implications", 6-7 August 2004, Pokhara, Nepal. LI-BIRD, Biodiversity International and SDC. Local Initiatives for Biodiversity, 324: 54-65.

Gautam R, Sthapit B, Shrestha P. 2004. The role of home gardens to on-farm agro biodiversity Management and enhancing livelihoods of rural farmers of Nepal. On Farm Conservation of Agricultural biodiversity in Nepal: managing diversity and promoting its benefits.

Keatinge JD, Chadha ML, Hughes J d'A, Easdown WJ, Holmer RJ, Tenkouano A, Yang RY, Mavlyanova R, Neave S, AfariSefa V. 2012. Vegetable gardens and their impact on the attainment of the Millennium Development Goals. Biological Agriculture and Horticulture, 28(2): 71-85.

Kennedy G, Nantel G, Shetty P. 2003. The scourge of" hidden hunger": Global dimensions of micronutrient deficiencies. Food Nutrition and Agriculture, 32: 8-16.
Kumar BM, Nair PR. 2004. The enigma of tropical home gardens. Agroforestry Systems, 61(1): 135-152.

Martin A, Oudwater N, Meadows K. 2000. Urban agriculture and the livelihoods of the poor in Southern Africa: Case studies from Cape Town and Pretoria, South Africa and Harare, Zimbabwe

Meinzen-Dick R, Behrman J, Menon P, Quisumbing A. 2012. Gender: A key dimension linking agricultural programs to improved nutrition and health. Reshaping Agriculture for Nutrition and Health, 16: 135-144

Musotsi AA, Sigot AJ, Onyango MA. 2008. The role of home gardens in household food security in Butter division of Western Kenya. African Journal of Food, Agriculture, Nutrition and Development, 8(4): 375-390

Nair PKR. 2001. Do tropical home gardens elude science, or is it the other way around? Agroforestry Systems, 53(2): 239-245

Pinstrup-Andersen P. 2009. Food security: definition and measurement. Food Security, 1: 5-7.

Shrestha P, Gautam R, Rana RB, Sthapit BR. 2001. Home gardens in Nepal: Status and scope for research and development. Home Gardens and in Situ Conservation of Plant Genetic Resources in Farming Systems, 17-19

Sthapit BR, Rana RB, Hue NN, Rijal DR. 2004. The diversity of taro and sponge gourds in traditional home gardens in Nepal and Vietnam. Home Gardens and Agrobiodiversity. Washington, DC: Smithsonian Books, 234-254

Thapa BB. 2004. Establishment of homestead garden. Bagwani Bani. Bagwani Kendra, Kirtipur, Kathmandu. (in Nepali), 11.

Trinh LN, Watson JW, Hue NN, De NN, Minh NV, Chu P, Sthapit BR, Eyzaguirre PB. 2003. Agrobiodiversity conservation and development in Vietnamese home gardens. Agriculture, Ecosystem and Environment, 97(1-3): 317-344

Vogl CR, Vogl-Lukasser B, Caballero J. 2002. Home gardens of Maya migrants in the district of Palenque (Chiapas/Mexico): Implications for sustainable rural development. Ethnobiology and Biocultural Diversity, 631-647. 